\title{
Correction to: Somewhere Between Love and Justice: a Roman Catholic Church in Paris Responds to the European Migration Crisis
}

\author{
Alexis Artaud de La Ferrière ${ }^{1,2}$
}

Published online: 17 July 2018

(C) The Author(s) 2018

\section{Correction to: Int J Polit Cult Soc (2018) https://doi.org/10.1007/s10767-018-9289-7}

The article Somewhere Between Love and Justice: a Roman Catholic Church in Paris Responds to the European Migration Crisis, written by Alexis Artaud de La Ferrière, was originally published electronically on the publisher's internet portal (currently SpringerLink) on May 31, 2018 without open access.

With the author(s)' decision to opt for Open Choice the copyright of the article changed on July 2018 to (C) The Author(s) 2018 and the article is forthwith distributed under the terms of the Creative Commons Attribution 4.0 International License (http://creativecommons. org/licenses/by/4.0/), which permits use, duplication, adaptation, distribution and reproduction in any medium or format, as long as you give appropriate credit to the original author(s) and the source, provide a link to the Creative Commons license and indicate if changes were made.

Open Access This article is distributed under the terms of the Creative Commons Attribution 4.0 International License (http://creativecommons.org/licenses/by/4.0/), which permits unrestricted use, distribution, and reproduction in any medium, provided you give appropriate credit to the original author(s) and the source, provide a link to the Creative Commons license, and indicate if changes were made.

The online version of the original article can be found at https://doi.org/10.1007/s10767-018-9289-7

Alexis Artaud de La Ferrière

alexis.delaferriere@gmail.com

1 Department of Politics and International Studies, SOAS, University of London, London, UK

2 Groupe Sociétés Religions, Laïcités (CNRS/EPHE), Paris, France 